\title{
Decarboxylative Suzuki-Miyaura Coupling of (hetero)aromatic carboxylic acids using lodine as the Terminal Oxidant
}

DOI:

10.1039/C9CC01817D

\section{Document Version}

Accepted author manuscript

Link to publication record in Manchester Research Explorer

Citation for published version (APA):

Quibell, J., Duan, G., Perry, G., \& Larrosa, I. (2019). Decarboxylative Suzuki-Miyaura Coupling of (hetero)aromatic carboxylic acids using lodine as the Terminal Oxidant. Chemical Communications.

https://doi.org/10.1039/C9CC01817D

\section{Published in:}

Chemical Communications

\section{Citing this paper}

Please note that where the full-text provided on Manchester Research Explorer is the Author Accepted Manuscript or Proof version this may differ from the final Published version. If citing, it is advised that you check and use the publisher's definitive version.

\section{General rights}

Copyright and moral rights for the publications made accessible in the Research Explorer are retained by the authors and/or other copyright owners and it is a condition of accessing publications that users recognise and abide by the legal requirements associated with these rights.

\section{Takedown policy}

If you believe that this document breaches copyright please refer to the University of Manchester's Takedown Procedures [http://man.ac.uk/04Y6Bo] or contact uml.scholarlycommunications@manchester.ac.uk providing relevant details, so we can investigate your claim.

\section{OPEN ACCESS}




\title{
Chemical Science
}

\section{EDGE ARTICLE}

\section{Decarboxylative Suzuki-Miyaura Coupling of (hetero)aromatic carboxylic acids using lodine as the Terminal Oxidant}

Received 00th January 20xx, Accepted 00th January 20xx

DOI: $10.1039 / \times 0 \times x 00000 x$

www.rsc.org/

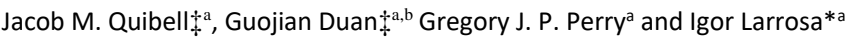

A novel methodology for the decarboxylative Suzuki-Miyaura-type coupling has been established. This process uses iodine or a bromine source as both the decarboxylation mediator and the terminal oxidant, thus avoiding the need for stoichiometric amounts of transition metal salts previously required. Our new protocol allows for the construction of valuable biaryl architectures through the coupling of (hetero)aromatic carboxylic acids with arylboronic acids. The scope of this decarboxylative Suzuki reaction has been greatly diversified, allowing for previously inaccessible non-ortho-substituted aromatic acids to undergo this transformation. The procedure also benefits from low catalyst loadings and the absence of stoichiometric transition metal additives.

\section{Introduction}

Over the last few decades, transition metal catalysed crosscoupling chemistry has redefined chemists' approaches to target synthesis. ${ }^{1}$ Among all the methods developed, the Suzuki-Miyaura reaction, coupling an organohalide with an organoboronic acid, has undoubtedly proved the most applicable in organic synthesis, as demonstrated by its wide use in the production of pharmaceuticals, natural products and materials. ${ }^{2}$ The synthetic utility of aryl boronic acids has led to the development of a wide variety of methodologies for their synthesis, ${ }^{3}$ including borylation of organo(pseudo)halides through transition metal catalysed ${ }^{4}$ or lithiation ${ }^{5}$ procedures, hydroboration, ${ }^{6}$ direct $\mathrm{C}-\mathrm{H}$ borylation ${ }^{7}$ and more recently decarboxylative borylation. ${ }^{8}$

Over the last decade, kick-started by the pioneering work of Gooßen, ${ }^{9}$ decarboxylative activation has paved the way for the use of readily available (hetero)aromatic carboxylic acids as coupling partners in cross-coupling reactions. ${ }^{10}$ Thus, a plethora of new methods have been developed for the decarboxylative coupling of these acids with aryl halides, ${ }^{11}$ pseudohalides, ${ }^{12}$ unactivated arenes through $\mathrm{C}-\mathrm{H}$ activation, ${ }^{13}$ and even double decarboxylative couplings; ${ }^{14}$ rapidly expanding the tools available for the synthesis of biaryls. However, despite the merits of decarboxylative couplings, most procedures come with some limitations. For example, ortho-substituents and high temperatures are often necessary to ensure efficient reactivity and stoichiometric transition metal additives, such as $\mathrm{Cu}$ - or Ag-salts, are required in many

\footnotetext{
a. School of Chemistry, University of Manchester, Oxford Road, Manchester, M13 9PL, United Kingdom.

b. College of Pharmacy, Gansu University of Chinese Medicine, Lanzhou 730000 China.

Electronic Supplementary Information (ESI) available: [details of any supplementary information available should be included here]. See DOI: 10.1039/x0xx00000x

\$ Jacob Quibell and Guojian Duan contributed equally to this work
}

Scheme 1. Coupling Methods.

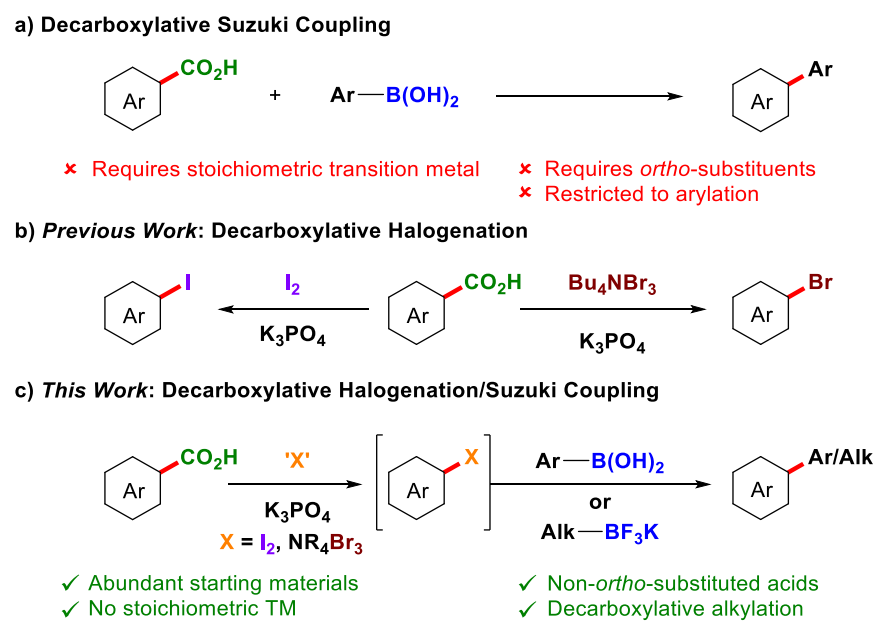

transformations. ${ }^{11,13}$ Furthermore, despite the popularity of organoboronic acids as coupling partners in cross-coupling reactions, only a handful of examples of decarboxylative Suzuki-Miyaura couplings have been reported to date (Scheme 1a). ${ }^{15,16}$ Furthermore, these methods suffer from extremely poor substrate scope (only ortho-substituted benzoic acids and often only 2,6-dimethoxy benzoic acid reacts efficiently), the need for high catalyst loadings (10-20 mol \% of Pd), and superstoichiometric silver salt oxidants (2-3 equiv). Given the wide availability of aryl boronic acids, a general methodology for decarboxylative Suzuki-Miyaura couplings using low Pdcatalyst loadings and avoiding stoichiometric transition metal oxidants would be highly desirable.

We have recently reported a novel approach to decarboxylative activation that uses iodine and bromine sources to mediate a decarboxylative iodination and bromination, respectively (Scheme 1 b). ${ }^{17,18}$ These 
transformations proceed efficiently on electron-rich aryl and heteroaryl carboxylic acids, even in the absence of orthosubstituents. Based on this novel decarboxylative activation mode, we now report the development of a decarboxylative Suzuki-Miyaura coupling allowing for the first time the use of non-ortho-substituted benzoic acids with arylboronic acids as coupling partners, using only iodine or a bromine source as terminal oxidants (Scheme 1c).

\section{Results and Discussion}

Our strategy for a decarboxylative Suzuki-Miyaura coupling required the combination of three distinct steps in a one-pot process: 1) decarboxylative halogenation, 2) quench of any excess halogen and 3) coupling of the resulting aryl halide with a boronic acid. We initiated our studies by attempting the coupling of 4-methoxybenzoic acid (1a) with phenylboronic acid (2a, Table 1). Accordingly, 1a was treated with 3 equiv of $I_{2}$ in the presence of $\mathrm{K}_{3} \mathrm{PO}_{4}$ until complete formation of the corresponding aryl iodide. Addition of $\mathrm{Et}_{3} \mathrm{~N}$ efficiently removed the excess of $I_{2}$. This step was followed by addition of the arylboronic acid $\mathbf{2 a}$ along with a palladium catalyst, a base and any additional solvent required. Optimization of the coupling step revealed that common commercially available catalysts such as $\mathrm{Pd}(\mathrm{OAc})_{2}, \mathrm{PdCl}_{2}, \mathrm{PdCl}_{2} \mathrm{dppf}$ and $\mathrm{Pd}\left(\mathrm{PPh}_{3}\right)_{4}$ gave only modest yields (Table 1 , entries 1-4). Remarkably, the use of $\operatorname{Pd}(N, N \text {-dimethyl- } \beta \text {-alaninate })_{2},{ }^{19} \mathbf{P d}-\mathbf{A}$, gave an excellent yield using only $2 \mathrm{~mol} \%$ loading of this catalyst (table 1 , entry 5 ). Lower catalyst loadings and reaction temperature led to lower conversions (Table 1, entries 6-7).

This decarboxylative Suzuki-Miyaura reaction tolerates a wide range of aryl boronic acids; electron withdrawing paracyano (3b), nitro (3d), chloro (3e) and acetyl (3f) substituents all gave excellent yields, although when the cyano group was placed in the ortho-position (3c) a slight drop in the yield was observed. Electron rich $p$-tolyl $(\mathbf{3 g})$ and $o$-anisole boronic acids (3h) again showed excellent reactivity and even heteroaromatic boronic acids ( $\mathbf{3 i}$ and $\mathbf{3} \mathbf{j}$ ) gave moderate to

Table 1. Optimization of an iodine-mediated decarboxylative Suzuki-Miyaura reaction. ${ }^{a}$

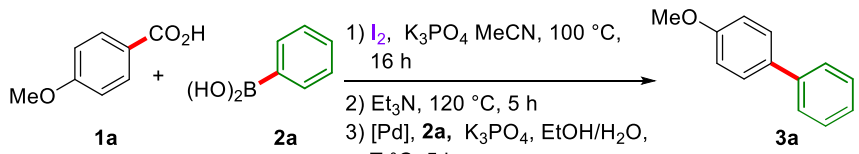

\begin{tabular}{|c|c|c|c|}
\hline Entry & [Pd] source & $\mathrm{T}\left({ }^{\circ} \mathrm{C}\right)$ & Yield $\mathbf{3 a}(\%)^{b}$ \\
\hline 1 & $\mathrm{Pd}(\mathrm{OAc})_{2}$ & 100 & 60 \\
\hline 2 & $\mathrm{PdCl}_{2}$ & 100 & 49 \\
\hline 3 & $\mathrm{PdCl}_{2} \mathrm{dppf}$ & 100 & 52 \\
\hline 4 & $\mathrm{Pd}\left(\mathrm{PPh}_{3}\right)_{4}$ & 100 & 46 \\
\hline 5 & Pd-A & 100 & 92 \\
\hline 6 & Pd-A & 80 & 87 \\
\hline 7 & $\mathbf{P d}-\mathbf{A}^{c}$ & 100 & 79 \\
\hline
\end{tabular}

${ }^{a}$ Reaction conditions: $1.1 \mathrm{a}(0.5 \mathrm{mmol}), \mathrm{I}_{2}$ (3 equiv), $\mathrm{K}_{3} \mathrm{PO}_{4}$ (1 equiv), $\mathrm{MeCN}(0.66 \mathrm{M})$, $100{ }^{\circ} \mathrm{C}, 16$ h. 2 . $\mathrm{Et}_{3} \mathrm{~N}$ (4.5 equiv), $120^{\circ} \mathrm{C}, 5$ h. 3. [Pd] ( $2 \mathrm{~mol} \%$ ), $2 \mathrm{a}$ (1.5 equiv), $\mathrm{K}_{3} \mathrm{PO}_{4}(1.5$ equiv), $\mathrm{EtOH} / \mathrm{H}_{2} \mathrm{O}(1: 1,1.5 \mathrm{~mL}) . \mathrm{Pd}-\mathrm{A}=\mathrm{Pd}(\mathrm{N}, \mathrm{N} \text {-dimethyl- } \beta \text {-alaninate })_{2 .}{ }^{b}$ Yields calculated by ${ }^{1} \mathrm{H}$ NMR with $\mathrm{CH}_{2} \mathrm{Br}_{2}$ as an internal standard. ${ }^{c} 1 \mathrm{~mol} \%$ of Pd-A. excellent yields. Using (E)-styrylboronic acid as the coupling partner led to the corresponding (E)-stilbene (3k) with complete retention of stereochemistry. Notably, all of these couplings were performed using 4-methoxybenzoic acid as the coupling partner. Previous decarboxylative Suzuki couplings have been limited to ortho- substituted benzoic acids. Satisfyingly, a simple scaling up of the standard conditions allowed an excellent yield of $3 a$ to be obtained on a $10 \mathrm{mmol}$ scale, presenting this methodology as an easily scalable attractive process for industry ( $3 a$, Scheme 2 , footnote b).

Scheme 2. Scope of the Boronic Acid Coupling Partner. ${ }^{a}$

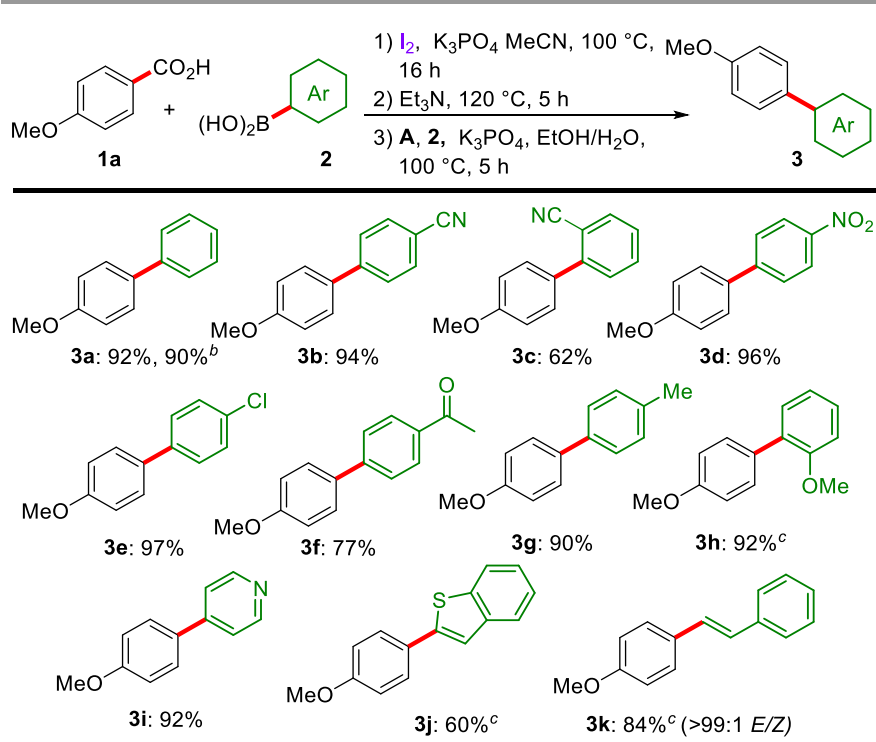

${ }^{a}$ Reaction conditions: 1) 1a (0.5 mmol), $\mathrm{I}_{2}$ (3 equiv), $\mathrm{K}_{3} \mathrm{PO}_{4}$ (1 equiv), $\mathrm{MeCN}(0.66 \mathrm{M})$, $100{ }^{\circ} \mathrm{C}, 16$ h. 2) $\mathrm{Et}_{3} \mathrm{~N}$ (4.5 equiv), $120^{\circ} \mathrm{C}, 5$ h. 3) $\mathrm{Pd}-\mathrm{A}=\mathrm{Pd}(\mathrm{N}, \mathrm{N} \text {-dimethyl- } \beta \text {-alaninate })_{2}(2$ mol \%), 2 (1.5 equiv), $\mathrm{K}_{3} \mathrm{PO}_{4}$ (1.5 equiv), $\mathrm{EtOH} / \mathrm{H}_{2} \mathrm{O}(1: 1,1.5 \mathrm{~mL})$. Yields given are isolated yields. ${ }^{b}$ Reaction run on $10 \mathrm{mmol}$ scale ${ }^{c}$ Boronic acid (2.0 equiv), $15 \mathrm{~h}$ reaction time in 3rd step.

Next our attention turned to the scope of the benzoic acid (Scheme 3). As we have reported previously, the decarboxylative iodination is limited to electron rich (hetero)aromatic carboxylic acids. ${ }^{17}$ Nevertheless, the range of carboxylic acid substrates compatible with this system proved to be diverse. The ortho-methoxy substituted acid $\mathbf{1}$ reacted well to give 31. Similarly, the highly electron rich substrates $\mathbf{1 m}$ and $\mathbf{1 n}$ gave good yields of $\mathbf{3 m}$ and $\mathbf{3 n}$, respectively, and due to the highly reactive nature of these acids to decarboxylative iodination the first step can be carried out at room temperature. The 3-methyl-4-methoxy substituted benzoic acid showed good conversion to 30 despite its lack of orthosubstituents and the polymethyl-derivative $\mathbf{3 p}$ was isolated in good yield despite its propensity to react sluggishly under traditional decarboxylative conditions. ${ }^{20}$ Electron withdrawing halogen substituents $(\mathbf{3 q}, \mathbf{3 r})$ were tolerated, provided a methoxy group was present. Polyfluorinated acids such as $1 \mathrm{~s}$ also undergo this transformation smoothly, to yield $3 \mathrm{~s}$; it is likely that in this case the decarboxylative iodination step occurs via a different mechanism to the electron rich aromatic acids. ${ }^{17 a}$ Heteroaromatic benzoic acids, such as nicotinic acid 
(to $3 \mathbf{t}-\mathbf{v}$ ), benzofuran- (to $3 \mathbf{w}-\mathbf{y}$ ) and benzo[b]thiophenecarboxylic acids, (to $\mathbf{3 z}$ ) gave excellent yields under these conditions. Chromone and pyrazole substrates (to 3aa and 3ab, respectively) gave also good yields although 2 equiv of phenyl boronic acid and longer reaction times were necessary in these cases. Finally, the furan carboxylic acid substrate 1ac afforded moderate yields of 3ac. The scope on the carboxylic acids aryl donor presents a significant improvement on previous methods which usually provide good yields only with highly electron rich, polymethoxy-substituted benzoic acids or azaindole-2-carboxylic acid derivatives. ${ }^{15}$

Scheme 3. Scope of the (Hetero)aromatic Acid Coupling Partner. ${ }^{a}$

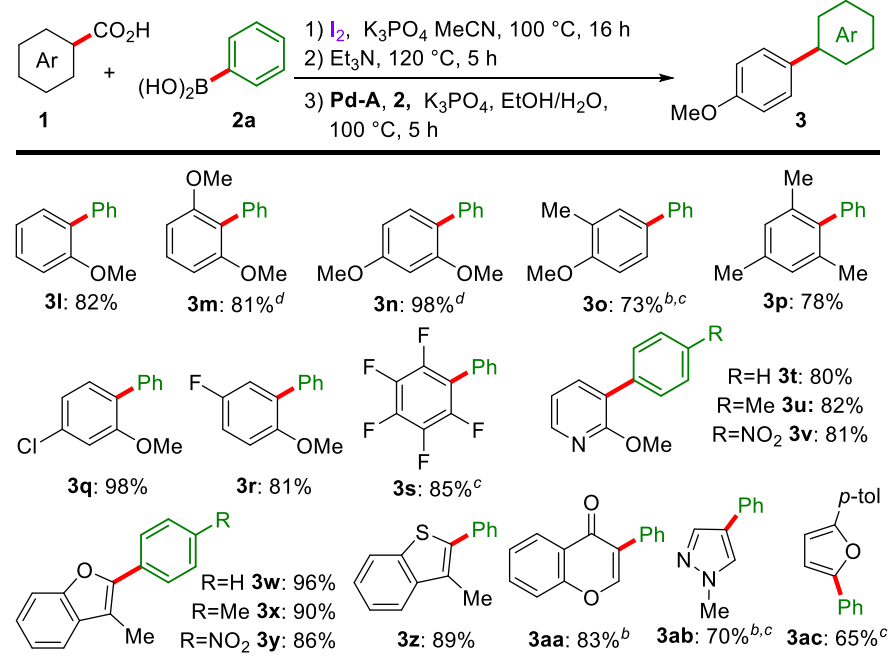

${ }^{a}$ Reaction conditions: 1) 1a (0.5 mmol), $\mathrm{I}_{2}$ (3 equiv), $\mathrm{K}_{3} \mathrm{PO}_{4}$ (1 equiv), $\mathrm{MeCN}(0.66 \mathrm{M})$, $100{ }^{\circ} \mathrm{C}, 16$ h. 2) $\mathrm{Et}_{3} \mathrm{~N}$ (4.5 equiv), $120^{\circ} \mathrm{C}, 5$ h. 3) $\mathbf{P d}-\mathrm{A}=\mathrm{Pd}(\mathrm{N}, \mathrm{N} \text {-dimethyl- } \beta \text {-alaninate })_{2}(2$ $\mathrm{mol} \%), 2$ (1.5 equiv), $\mathrm{K}_{3} \mathrm{PO}_{4}$ (1.5 equiv), $\mathrm{EtOH} / \mathrm{H}_{2} \mathrm{O}(1: 1,1.5 \mathrm{~mL}$ ). Yields given are isolated yields. ${ }^{b} \mathbf{2}$ (2.0 equiv). ${ }^{c} 15 \mathrm{~h}$ reaction time in $3^{\text {rd }}$ step. ${ }^{d} \sim 20{ }^{\circ} \mathrm{C}$ reaction temperature in $1^{\text {st }}$ step.

Scheme 4. Scope of the Decarboxylative Suzuki-Miyaura Coupling Mediated by ${ }^{n} \mathrm{Bu}_{4} \mathrm{NBr}_{3} .{ }^{\circ}$
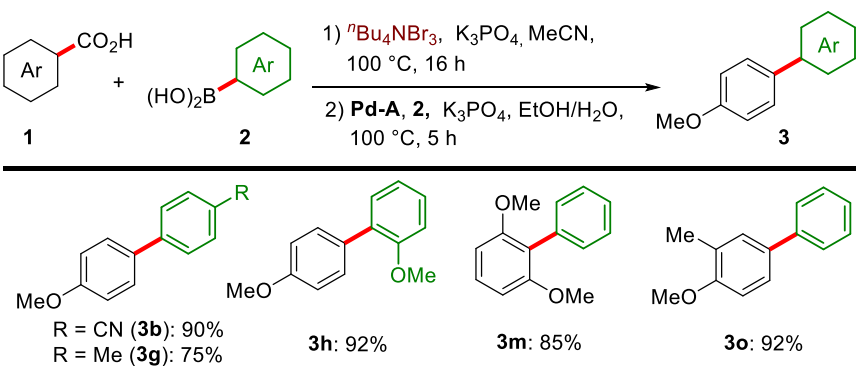

${ }^{a}$ Reaction conditions: 1 ) 1 a ( $0.5 \mathrm{mmol}$ ), ${ }^{n} \mathrm{Bu}_{4} \mathrm{NBr}_{3}$ (2 equiv), $\mathrm{K}_{3} \mathrm{PO}_{4}$ (1 equiv), MeCN (0.66 $\mathrm{M}), 100{ }^{\circ} \mathrm{C}, 16$ h. 2) $\mathbf{P d}-\mathrm{A}=\mathrm{Pd}(\mathrm{N}, \mathrm{N} \text {-dimethyl- } \beta \text {-alaninate })_{2}(2 \mathrm{~mol} \%), 2$ (1.5 equiv), $\mathrm{K}_{3} \mathrm{PO}_{4}$ (1.5 equiv), $\mathrm{EtOH} / \mathrm{H}_{2} \mathrm{O}(1: 1,1.5 \mathrm{~mL}$ ). Yields given are isolated yields.

Following our report on decarboxylative iodination, ${ }^{17 a}$ we also developed an analogous decarboxylative bromination procedure. ${ }^{17 \mathrm{~b}}$ This represents a more reactive system that generally requires fewer equivalents of the halogenating agent. We therefore explored the development of a decarboxylative Suzuki-Miyaura coupling using a bromine source terminal oxidant as a complementary strategy. We followed a similar procedure as that for the iodine mediated decarboxylative Suzuki-Miyaura coupling, however, ${ }^{n} \mathrm{Bu}_{4} \mathrm{NBr}_{3}$ was used as the halogenating agent. In this case, we found $\mathrm{Et}_{3} \mathrm{~N}$ was not required in the second step; instead, the solvent was removed under vacuum after the first step, before carrying out the cross-coupling. Under these conditions the majority of the coupling products gave comparable yields to

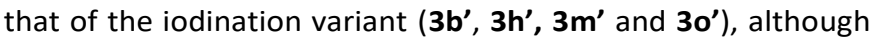
a drop in yield was seen in the case of $\mathbf{3} \mathbf{g}^{\prime}$.

\section{Conclusions}

Using iodine or a bromine source as the decarboxylation mediator and terminal oxidants has allowed the development of a novel decarboxylative Suzuki-Miyaura cross-coupling. The scope of this protocol vastly improves upon previous examples of the methodology: the common requirement of an orthosubstituent is now avoided and heteroaromatic substrates can now be chosen as either coupling partner. This strategy has also allowed for low catalyst loadings and the avoidance of stoichiometric transition metals. In addition the reaction can be scaled up with minimal loss of reactivity.

\section{Conflicts of interest}

There are no conflicts to declare.

\section{ACKNOWLEDGMENT}

We gratefully acknowledge the University of Manchester School of Chemistry for funding (to G.J.P.P.). We also thank the National Natural Science Foundation of China (Nos. 21762001) and the China Scholarship Council for a visiting scholarship (to G.D.).

\section{References}

1 (a) J. Hassan, M. Sévignon, C. Gozzi, E. Schulz and M. Lemaire, Chem. Rev., 2002, 102, 1359-1470. (b) C. C. C. Johansson Seechurn, M. O. Kitching, T. J. Colacot and V. Snieckus, Angew. Chem. Int. Ed., 2012, 51, 5062-5085. (c) D. Roy, Y. Uozumi, Adv. Synth. Catal. 2018, 360, 602-625.

2 (a) S. R. Chemler, D. Trauner and S. J. Danishefsky, Angew. Chem. Int. Ed., 2001, 40, 4544-4568. (b) K. C. Nicolau, P. G. Bulger, D. Sarlah, Angew. Chem. Int. Ed., 2005, 44, 44424489. (c) C. Torborg and M. Beller, Adv. Synth. Catal., 2009, 351, 3027-3043.

3 D. G. Hall, in Boronic Acids, Wiley-Blackwell, 2011, pp. 1-133.

4 For selected examples see: (a) T. Ishiyama, M. Murata and N. Miyaura, J. Org. Chem., 1995, 60, 7508-7510. (b) B. H. Lipshutz, R. Moser and K. R. Voigtritter, Isr. J. Chem., 2010, 50, 691-695. (c) G. A. Molander, S. L. J. Trice and S. D. Dreher, J. Am. Chem. Soc., 2010, 132, 17701-17703. (d) A. S. Dudnik and G. C. Fu, J. Am. Chem. Soc., 2012, 134, 1069310697. For representative reviews see: (e) T. Ishiyama and N. Miyaura, Chem. Rec., 2004, 3, 271-280. (f) L. T. Pilarski and K. J. Szabó, Angew. Chem. Int. Ed., 2011, 50, 8230-8232. (g) W. K. Chow, O. Y. Yuen, P. Y. Choy, C. M. So, C. P. Lau, W. T. Wong and F. Y. Kwong, RSC Adv., 2013, 3, 12518-12539. 
5 For selected examples see: (a) H. Gilman, L. Santucci, D. R. Swayampati and R. O. Ranck, J. Am. Chem. Soc., 1957, 79, 3077-3081. (b) R. T. Hawkins and D. B. Stroup, J. Org. Chem., 1969, 34, 1173-1174. (c) H. C. Brown and T. E. Cole, Organometallics, 1983, 2, 1316-1319. (d) H. C. Brown, M. Srebnik and T. E. Cole, Organometallics, 1986, 5, 2300-2303. (e) W. Li, D. P. Nelson, M. S. Jensen, R. S. Hoerrner, D. Cai, R. D. Larsen and P. J. Reider, J. Org. Chem., 2002, 67, 53945397. (f) J. L. Stymiest, V. Bagutski, R. M. French and V. K. Aggarwal, Nature, 2008, 456, 778-782. (g) D. L. Browne, M. Baumann, B. H. Harji, I. R. Baxendale and S. V. Ley, Org. Lett., 2011, 13, 3312-3315.

6 For selected examples see: (a) H. C. Brown and B. C. S. Rao, J. Am. Chem. Soc., 1956, 78, 5694-5695. (b) H. C. Brown and G. Zweifel, J. Am. Chem. Soc., 1961, 83, 486-487. (c) H. C. Brown, Tetrahedron, 1961, 12, 117-138. (d) S. P. Thomas and V. K. Aggarwal, Angew. Chem. Int. Ed., 2009, 48, 18961898. (e) J. V. Obligacion and P. J. Chirik, Org. Lett., 2013, 15, 2680-2683. (f) J. H. Docherty, J. Peng, A. P. Dominey and S. P. Thomas, Nat. Chem., 2017, 9, 595-600. (g) J. R. Smith, B. S. L. Collins, M. J. Hesse, M. A. Graham, E. L. Myers and V. K. Aggarwal, J. Am. Chem. Soc., 2017, 139, 9148-9151. (h) J. R. Carney, B. R. Dillon, L. Campbell and S. P. Thomas, Angew. Chem. Int. Ed., 2018, 57, 10620-10624. For representative reviews see: (i) K. Burgess and M. J. Ohlmeyer, Chem. Rev. 1991, 91, 1179-1191. (j) C. M. Crudden and D. Edwards, Eur. J. Org. Chem., 2003, 2003, 4695-4712. (k) C. C. Chong and R. Kinjo, ACS Catal., 2015, 5, 3238-3259.

7 For selected examples see: (a) K. M. Waltz, X. He, C. Muhoro and J. F. Hartwig, J. Am. Chem. Soc., 1995, 117, 1135711358. (b) S. Shimada, A. S. Batsanov, J. A. K. Howard and T. B. Marder, Angew. Chem. Int. Ed., 2001, 40, 2168-2171. (c) T. Ishiyama, J. Takagi, K. Ishida, N. Miyaura, N. R. Anastasi and J. F. Hartwig, J. Am. Chem. Soc., 2002, 124, 390-391. (d) J.-Y. Cho, M. K. Tse, D. Holmes, R. E. Maleczka and M. R. Smith, Science, 2002, 295, 305-308. (e) D. W. Robbins, T. A Boebel and J. F. Hartwig, J. Am. Chem. Soc., 2010, 132, 40684069. (f) H.-X. Dai and J.-Q. Yu, J. Am. Chem. Soc., 2012, 134, 134-137. (g) P. C. Roosen, V. A. Kallepalli, B. Chattopadhyay, D. A. Singleton, R. E. Maleczka and M. R. Smith, J. Am. Chem Soc., 2012, 134, 11350-11353. (h) T. J. Mazzacano and N. P. Mankad, J. Am. Chem. Soc., 2013, 135, 17258-17261. (i) Y Saito, Y. Segawa and K. Itami, J. Am. Chem. Soc., 2015, 137, 5193-5198 (j) T. Furukawa, M. Tobisu and N. Chatani, J. Am. Chem. Soc., 2015, 137, 12211-12214. (k) J. V. Obligacion, S. P. Semproni, I. Pappas and P. J. Chirik, J. Am. Chem. Soc. 2016, 138, 10645-10653. (I) B. E. Haines, Y. Saito, Y. Segawa, K. Itami and D. G. Musaev, ACS Catal., 2016, 6, 7536-7546. (m) N. G. Léonard, M. J. Bezdek and P. J. Chirik, Organometallics, 2017, 36, 142-150. (n) J. Légaré Lavergne, A. Jayaraman, L. C. Misal Castro, É. Rochette and F.-G. Fontaine, J. Am. Chem. Soc., 2017, 139, 14714-14723.L. Xu, Eur. J. Org. Chem., 2018, 2018, 3884-3890.

8 (a) C. Li, J. Wang, L. M. Barton, S. Yu, M. Tian, D. S. Peters, M. Kumar, A. W. Yu, K. A. Johnson, A. K. Chatterjee, M. Yan and P. S. Baran, Science, 2017, 356, 1045. (b) L. Candish, M. Teders and F. Glorius, J. Am. Chem. Soc., 2017, 139, 74407443. (c) A. Fawcett, J. Pradeilles, Y. Wang, T. Mutsuga, E. L. Myers and V. K. Aggarwal, Science, 2017, 357, 283. (d) W.-M. Cheng, R. Shang, B. Zhao, W.-L. Xing and Y. Fu, Org. Lett., 2017, 19, 4291-4294. (e) J. Wang, M. Shang, H. Lundberg, K. S. Feu, S. J. Hecker, T. Qin, D. G. Blackmond and P. S. Baran, ACS Catal., 2018, 8, 9537-9542.

9 L. J. Gooßen, G. Deng and L. M. Levy, Science, 2006, 313, 662-664.

10 For representative reviews see: (a) L. J. Gooßen, K. Gooßen, N. Rodríguez, M. Blanchot, C. Linder and B. Zimmermann, Pure Appl. Chem., 2008, 80, 1725-1733. (b) L. J. Gooßen, N.
Rodríguez and K. Gooßen, Angew. Chem. Int. Ed., 2008, 47, 3100-3120. (c) N. Rodríguez and L. J. Goossen, Chem. Soc. Rev., 2011, 40, 5030-5048. (d) R. Shang and L. Liu, Sci. China Chem., 2011, 54, 1670-1687. (e) L. J. Gooßen and K. Gooßen, in Inventing Reactions, Springer, Berlin, Heidelberg, 2012, pp. 121-141. (f) J. Cornella and I. Larrosa, Synthesis, 2012, 44, 653-676. (g) W. I. Dzik, P. P. Lange and L. J. Gooßen, Chem. Sci., 2012, 3, 2671-2678. (h) G. J. P. Perry and I. Larrosa, Eur. J. Org. Chem., 2017, 2017, 3517-3527. (i) Y. Wei, P. Hu, M Zhang and W. Su, Chem. Rev., 2017, 117, 8864-8907.

11 For selected examples see: (a) L. J. Goossen, N. Rodríguez, B. Melzer, C. Linder, G. Deng and L. M. Levy, J. Am. Chem. Soc., 2007, 129, 4824-4833. (b) J.-M. Becht, C. Catala, C. Le Drian and A. Wagner, Org. Lett., 2007, 9, 1781-1783. (c) L. J. Gooßen, B. Zimmermann and T. Knauber, Angew. Chem. Int. Ed., 2008, 47, 7103-7106. (d) F. Zhang and M. F. Greaney, Org. Lett., 2010, 12, 4745-4747.J. Tang, A. Biafora and L. J. Goossen, Angew. Chem. Int. Ed., 2015, 54, 13130-13133.

12 For selected examples see: (a) L. J. Goossen, N. Rodríguez and C. Linder, J. Am. Chem. Soc., 2008, 130, 15248-15249. (b) L. J. Gooßen, N. Rodríguez, P. P. Lange and C. Linder, Angew. Chem. Int. Ed., 2010, 49, 1111-1114.

13 For selected examples see: (a) A. Voutchkova, A. Coplin, N. E. Leadbeater and R. H. Crabtree, Chem. Commun., 2008, 6312-6314. (b) C. Wang, I. Piel and F. Glorius, J. Am. Chem. Soc., 2009, 131, 4194-4195. (c) J. Cornella, P. Lu and I. Larrosa, Org. Lett., 2009, 11, 5506-5509. (d) F. Zhang and M. F. Greaney, Angew. Chem. Int. Ed., 2010, 49, 2768-2771. (e) K. Xie, Z. Yang, X. Zhou, X. Li, S. Wang, Z. Tan, X. An and C.-C. Guo, Org. Lett., 2010, 12, 1564-1567. (f) H. Zhao, Y. Wei, J. Xu, J. Kan, W. Su and M. Hong, J. Org. Chem., 2011, 76, 882893. (g) P. Hu, M. Zhang, X. Jie and W. Su, Angew. Chem., 2012, 124, 231-235. (h) J. M. Crawford, K. E. Shelton, E. K. Reeves, B. K. Sadarananda and D. Kalyani, Org. Chem., 2015, 2, 726-729. (i) T. Patra, S. Nandi, S. K. Sahoo and D. Maiti, Chem. Commun., 2016, 52, 1432-1435.

14 (a) J. Cornella, H. Lahlali and I. Larrosa, Chem. Commun., 2009, 46, 8276-8278. (b) K. Xie, S. Wang, Z. Yang, J. Liu, A. Wang, X. Li, Z. Tan, C.-C. Guo and W. Deng, Eur. J. Org. Chem., 2011, 2011, 5787-5790. (c) P. Hu, Y. Shang and W. Su, Angew. Chem. Int. Ed., 2012, 51, 5945-5949. (d) H.-Y. Gao, P. A. Held, M. Knor, C. Mück-Lichtenfeld, J. Neugebauer, A. Studer and H. Fuchs, J. Am. Chem. Soc., 2014, 136, 96589663. (e) Z. Fu, Z. Li, Q. Xiong and H. Cai, RSC Adv., 2015, 5, 52101-52104.

15 (a) J.-J. Dai, J.-H. Liu, D.-F. Luo and L. Liu, Chem. Commun. 2011, 47, 677-679. (b) R. Suresh, S. Muthusubramanian, R. S. Kumaran and G. Manickam, Asian J. Org. Chem., 2013, 2, 169-175. (c) A. Wang, X. Li, J. Liu, Q. Gui, X. Chen, Z. Tan and K. Xie, Synth. Commun., 2014, 44, 289-295. (d) T. Mino, E. Yoshizawa, K. Watanabe, T. Abe, K. Hirai and M. Sakamoto, Tetrahedron Lett., 2014, 55, 3184-3188.

16 For an example using $\alpha$-oxocarboxylic acids see: $M$. Li, C. Wang and H. Ge, Org. Lett., 2011, 13, 2062-2064.

17 (a) G. J. P. Perry, J. M. Quibell, A. Panigrahi and I. Larrosa, J. Am. Chem. Soc., 2017, 139, 11527-11536. (b) J. M. Quibell, G. J. P. Perry, D. M. Cannas and I. Larrosa, Chem. Sci., 2018, 9, 3860-3865.

18 For a recent example of decarboxylative Sonogashira via decarboxylative bromination see: Q. Jiang, H. Li, X. Zhang, B. Xu and W. Su, Org. Lett., 2018, 20, 2424-2427.

19 (a) X. Cui, T. Qin, J.-R. Wang, L. Liu and Q.-X. Guo, Synthesis, $2007,2007,393-399$. (b) for a study into the role of the catalyst please see: X. Cui, Z. Li, C.-Z. Tao, Y. Xu, J. Li, L. Liu and Q.-X. Guo, Org. Lett., 2006, 8, 2467-2470

20 J. S. Dickstein, J. M. Curto, O. Gutierrez, C. A. Mulrooney and M. C. Kozlowski, J. Org. Chem., 2013, 78, 4744-4761. 
Journal Name

\section{Entry for the graphical abstract}

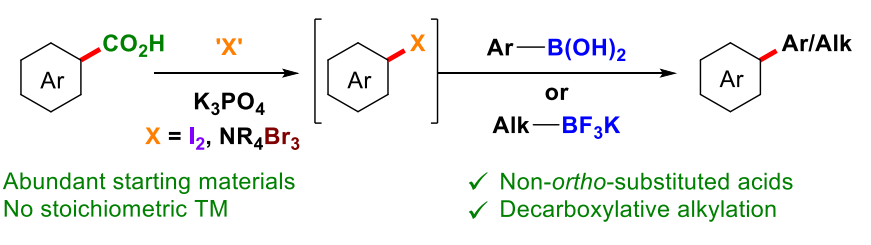

